\title{
Oxygen isotope ratios in the shell of Mytilus edulis: archives of glacier meltwater in Greenland?
}

\author{
E. A. A. Versteegh ${ }^{1}$, M. E. Blicher ${ }^{2}$, J. Mortensen $^{2}$, S. Rysgaard ${ }^{2,3,4}$, T. D. Als ${ }^{5}$, and A. D. Wanamaker Jr. ${ }^{6}$ \\ ${ }^{1}$ Department of Geography and Environmental Science, University of Reading, Reading, UK \\ ${ }^{2}$ Greenland Climate Research Centre, Greenland Institute of Natural Resources, Nuuk, Greenland \\ ${ }^{3}$ Centre for Earth Observation Science, University of Manitoba, Winnipeg, Manitoba, Canada \\ ${ }^{4}$ Arctic Research Centre, Aarhus University, Århus C, Denmark \\ ${ }^{5}$ National Institute of Aquatic Resources, Technical University of Denmark, Silkeborg, Denmark \\ ${ }^{6}$ Department of Geological and Atmospheric Sciences, Iowa State University, Ames IA, USA
}

Correspondence to: E. Versteegh (e.a.versteegh@reading.ac.uk)

Received: 15 August 2012 - Published in Biogeosciences Discuss.: 5 September 2012

Revised: 8 November 2012 - Accepted: 29 November 2012 - Published: 18 December 2012

\begin{abstract}
Melting of the Greenland Ice Sheet (GrIS) is accelerating and will contribute significantly to global sea level rise during the 21 st century. Instrumental data on GrIS melting only cover the last few decades, and proxy data extending our knowledge into the past are vital for validating models predicting the influence of ongoing climate change. We investigated a potential meltwater proxy in Godthåbsfjord (West Greenland), where glacier meltwater causes seasonal excursions with lower oxygen isotope water $\left(\delta^{18} \mathrm{O}_{\mathrm{w}}\right)$ values and salinity. The blue mussel (Mytilus edulis) potentially records these variations, because it precipitates its shell calcite in oxygen isotopic equilibrium with ambient seawater. As $M$. edulis shells are known to occur in raised shorelines and archaeological shell middens from previous Holocene warm periods, this species may be ideal in reconstructing past meltwater dynamics. We investigate its potential as a palaeo-meltwater proxy. First, we confirmed that M. edulis shell calcite oxygen isotope $\left(\delta^{18} \mathrm{O}_{\mathrm{c}}\right)$ values are in equilibrium with ambient water and generally reflect meltwater conditions. Subsequently we investigated if this species recorded the full range of $\delta^{18} \mathrm{O}_{\mathrm{w}}$ values occurring during the years 2007 to 2010 . Results show that $\delta^{18} \mathrm{O}_{\mathrm{w}}$ values were not recorded at very low salinities $(<\sim 19)$, because the mussels appear to cease growing. This implies that $M$. edulis $\delta^{18} \mathrm{O}_{\mathrm{c}}$ values are suitable in reconstructing past meltwater amounts in most cases, but care has to be taken that shells are collected not too close to a glacier, but rather in the midregion or mouth of the fjord. The focus of future research
\end{abstract}

will expand on the geographical and temporal range of the shell measurements by sampling mussels in other fjords in Greenland along a south-north gradient, and by sampling shells from raised shorelines and archaeological shell middens from prehistoric settlements in Greenland.

\section{Introduction}

The Greenland Ice Sheet (GrIS) is the world's second largest ice mass. Current global warming causes accelerated melting (Andresen et al., 2012; Howat et al., 2005; Rignot and Kanagaratnam, 2006), resulting in increased runoff since the early 1990s (Box et al., 2006; Hanna et al., 2011) and significantly contributing to global sea level rise (IPCC, 2007; Krabill et al., 2000; Price et al., 2011). The natural variability in GrIS mass balance over time is reconstructed by means of modelling studies, using instrumental data (covering the most recent decades) and proxy data (Alley et al., 2010; Israelson et al., 1994). Uncertainties in model projections are still considerable (Applegate et al., 2012; IPCC, 2007). In order to reduce these uncertainties and validate models, it is vital to collect proxy data on past ice sheet behaviour, such as surface mass balance and runoff (Alley et al., 2010; Applegate et al., 2012; Hanna et al., 2011).

Sclerochemical analysis of the marine bivalve Mytilus edulis (blue mussel) may provide such valuable information. The species is common in West and South Greenland, but 
currently absent north of central East Greenland. Subfossil shells, however, can be found in archaeological shell middens of prehistoric people, and raised palaeo-shorelines dating to 5500-8000 before present (BP) (Hjort and Funder, 1974; McGovern et al., 1996). As such there is a rich supply of shells from previous Holocene warm periods, potentially giving insight in GrIS dynamics during those time intervals.

Many biomineralising organisms faithfully record environmental variability in the chemistry of growth increments in their skeletons, e.g. corals (Swart, 1983; Watanabe et al., 2011), coralline algae (Halfar et al., 2008; Williams et al., 2011), land snails (Goodfriend and Ellis, 2002; Yanes et al., 2011), freshwater snails (Abell and Hoelzmann, 2000; Stevens et al., 2012), freshwater bivalves (Kaandorp et al., 2003; Versteegh et al., 2010b, 2011) and marine bivalves (Jones and Quitmyer, 1996; Santos et al., 2012; Schöne et al., $2005)$. The oxygen isotope composition $\left(\delta^{18} \mathrm{O}\right.$ values $)$ of marine bivalves is often used as a proxy for temperature (Carré et al., 2005; Wanamaker et al., 2011). It can, however, also be applied to reconstruct water $\delta^{18} \mathrm{O}\left(\delta^{18} \mathrm{O}_{\mathrm{w}}\right)$ values (Freitas et al., 2012; Khim, 2002), which usually directly relate with salinity (Ingram et al., 1996).

M. edulis produces prominent annual growth increments (Richardson et al., 1990) and precipitates its shell in oxygen isotopic equilibrium with the environment (Wanamaker et al., 2006, 2007). In combination with its wide geographic distribution, and its common occurrence in the archaeological and (sub-) fossil record, this makes the species highly suitable for reconstructing pre-instrumental temperatures or salinities. These applications, however, have so far been limited. Donner and Nord (1986) showed that M. edulis calcite $\delta^{18} \mathrm{O}\left(\delta^{18} \mathrm{O}_{\mathrm{c}}\right)$ values reflect water composition, and can be used to estimate past temperatures. Ingram et al. (1996) demonstrated that the amount of freshwater discharge into San Francisco Bay is accurately reflected in shell $\delta^{18} \mathrm{O}_{\mathrm{c}}$ values, and that $M$. edulis shells can be used to reconstruct preinstrumental freshwater fluxes. Here we investigate the potential of $\delta^{18} \mathrm{O}_{\mathrm{c}}$ records of $M$. edulis in the reconstruction of past glacier meltwater fluxes in a Greenland fjord.

We aim to establish if the shell $\delta^{18} \mathrm{O}_{\mathrm{c}}$ composition of $M$. edulis can be used as a proxy for ambient $\delta^{18} \mathrm{O}_{\mathrm{w}}$ values, reflecting the amount of meltwater, in Godthåbsfjord, West Greenland. We pose the following research questions:

1. Does the mixing of seawater and meltwater in the fjord yield a linear relationship between salinity and $\delta^{18} \mathrm{O}_{\mathrm{w}}$ values?

2. Do seasonal $\delta^{18} \mathrm{O}_{\mathrm{c}}$ records accurately reflect the full seasonal $\delta^{18} \mathrm{O}_{\mathrm{w}}$ cycle, including $\delta^{18} \mathrm{O}_{\mathrm{w}}$ excursions that are coincident with glacier meltwater input?

\section{Material and methods}

\subsection{Study area}

The Godthåbsfjord is situated in the sub-Arctic SW Greenland $\left(64^{\circ} \mathrm{N}, 51^{\circ} \mathrm{W}\right.$; Fig. 1). The fjord system is made up of a number of fjord branches. Tidal range varies from 1 to $5 \mathrm{~m}$ (Richter et al., 2011). The inner part of the main fjord is in contact with three tidal outlet glaciers. The distance from the mouth to the head of the fjord is $187 \mathrm{~km}$. A general description of bathymetry and water masses in the fjord is provided by Mortensen et al. (2011).

\subsection{Shell collection and water monitoring}

In May 2010 and June 2011, 10 M. edulis specimens were collected in the low intertidal on rocky shores along a transect from the glacier to the mouth of Godthåbsfjord. They were all adults and varied between 55 and $81 \mathrm{~mm}$ in length (Fig. 1, Table 1). Soft tissues were removed and the rinsed shells were dried at $50^{\circ} \mathrm{C}$ for $24 \mathrm{~h}$.

At time intervals of 2 to 4 weeks, water samples were collected at $1 \mathrm{~m}$ depth for oxygen isotope analyses. Water temperature and salinity were measured using a Sea-Bird Electronics SBE 19plus SEACAT Profiler CTD (conductivity, temperature and depth). The SBE 19plus was calibrated by the manufacturer every 1-2 yr, and uncertainties of the salinity after calibration were typically within the range $0.005-$ 0.010 . Temperature uncertainties were near to the initial accuracy of the instrument of $0.005^{\circ} \mathrm{C}$. At location GF3 monitoring started on 5 October 2005; at locations GF10 and GF5 measurements started on 9 January 2009 and 16 May 2009, respectively (Fig. 1). For oxygen isotope analysis, $2 \mathrm{~mL}$ water samples from each station were collected in gas-tight vials and analysed on a Picarro Isotopic Water Analyzer, L2120-I (Picarro, Sunnyvale, CA, USA). Water samples were introduced into the vaporization chamber using an attached PAL autosampler (Leap Technologies, Carrboro, NC, USA). Each sample was analysed three times (three consecutive replicate injections; $\sigma<0.005-0.007 \%$ o) alongside a set of three laboratory reference materials, which had previously been calibrated to the VSMOW (Vienna Standard Mean Ocean Water) scale (Coplen, 1994).

\subsection{Genetic identification}

In the North Atlantic two species of Mytilus can be found: M. edulis and M. trossulus (McDonald et al., 1991; Varvio et al., 1988) sometimes occurring together and interbreeding (Riginos and Cunningham, 2005). Since these species cannot be distinguished solely on morphological grounds, DNA fingerprinting was performed using four PCR (polymerase chain reaction)-based nuclear markers (two RFLP (restriction fragment length polymorphism) markers) to determine the species of the shells collected. These markers are diagnostic for M. edulis, M. trossulus, and M. galloprovincialis. 
Table 1. Specifications of shell samples.

\begin{tabular}{lccc}
\hline Sample ID & Location & Collection date & Shell length (mm) \\
\hline Godthåbsfjord archipelago 1a & $64^{\circ} 02.003^{\prime} \mathrm{N}, 51^{\circ} 45.592^{\prime} \mathrm{W}$ & $14 / 05 / 2010$ & 71 \\
Godthåbsfjord archipelago 1b & $64^{\circ} 02.003^{\prime} \mathrm{N}, 51^{\circ} 45.592^{\prime} \mathrm{W}$ & $14 / 05 / 2010$ & 68 \\
Nipisat Sound 2 & $64^{\circ} 11.088^{\prime} \mathrm{N}, 51^{\circ} 55.127^{\prime} \mathrm{W}$ & $14 / 05 / 2010$ & 68 \\
Ice Fjord north 3a & $64^{\circ} 38.679^{\prime} \mathrm{N}, 51^{\circ} 01.114^{\prime} \mathrm{W}$ & $01 / 06 / 2011$ & 53 \\
Ice Fjord north 3b & $64^{\circ} 38.679^{\prime} \mathrm{N}, 51^{\circ} 01.114^{\prime} \mathrm{W}$ & $01 / 06 / 2011$ & 61 \\
Ice Fjord south 4a & $64^{\circ} 38.354^{\prime} \mathrm{N}, 50^{\circ} 47.766^{\prime} \mathrm{W}$ & $01 / 06 / 2011$ & 77 \\
Ice Fjord south 4b & $64^{\circ} 38.354^{\prime} \mathrm{N}, 50^{\circ} 47.766^{\prime} \mathrm{W}$ & $01 / 06 / 2011$ & 81 \\
Akia 10a & $64^{\circ} 15.812^{\prime} \mathrm{N}, 51^{\circ} 43.908^{\prime} \mathrm{W}$ & $02 / 06 / 2011$ & 73 \\
Kapisillit 13a & $64^{\circ} 26.648^{\prime} \mathrm{N}, 50^{\circ} 13.397^{\prime} \mathrm{W}$ & $04 / 06 / 2011$ & 56 \\
Kapisillit 13b & $64^{\circ} 26.648^{\prime} \mathrm{N}, 50^{\circ} 13.397^{\prime} \mathrm{W}$ & $04 / 06 / 2011$ & 55 \\
\hline
\end{tabular}

Prior to DNA extraction, shells were washed in sterile deionised water and dried at $100^{\circ} \mathrm{C}$ in an incubator for $4 \mathrm{~h}$ (Doherty et al., 2007). DNA was extracted using the E.Z.N.A. kit (Omega Biotek, Norcross, GA, USA) following the manufacturer's protocol except for increased digestion time from 5 to $30 \mathrm{~h}$ (Doherty et al., 2007). The protocol for the two RFLP markers, Mal-1 treated with restriction enzyme SpeI and ITS followed by restriction with HhaI, is outlined in Rawson et al. (2001) and Heath et al. (1995), respectively. The applications of Glu-5 and Me 15/16 markers are outlined in Rawson et al. (1996a) and Inoue et al. (1995), respectively (Table 2). For three of the PCR-based markers, products were visualized on $2 \%$ agarose gels, while Me15/16 was analysed using an automated sequencer (ABI 3130 Genetic Analyser; Applied Biosystems, Foster City, CA, USA) due to relatively small differences in allele sizes (Inoue et al., 1995; Kijewski et al., 2009). For all four markers it was consistently confirmed that all 10 samples belong to M. edulis.

\subsection{Shell sampling and analysis}

One valve of each shell was embedded in epoxy resin, and a slab of $\sim 2 \mathrm{~mm}$ was cut along the longest growth axis. Powder samples for oxygen isotope analysis were drilled from the calcite outer layer, parallel to the internal growth lines, using a New Wave micromill. Drill bit diameter was $80 \mu \mathrm{m}$; sampling resolution varied between 250 and $1000 \mu \mathrm{m}$, and drilling depth was $\sim 500 \mu \mathrm{m}$.

Samples were measured via a Finnigan MAT Delta Plus XL mass spectrometer in continuous flow mode connected to a GasBench II with a CombiPAL autosampler at Iowa State University (Department of Geological and Atmospheric Sciences). Reference standards (NBS-18, NBS-19, LSVEC) were used for isotopic corrections, and to assign the data to the appropriate isotopic scale. At least one reference standard was used for every five samples. The average combined uncertainty ( $1 \sigma$ analytical uncertainty and average correction factor) for $\delta^{18} \mathrm{O}$ values was $\pm 0.12 \%$ (VPDB -Vienna Pee Dee Belemnite).

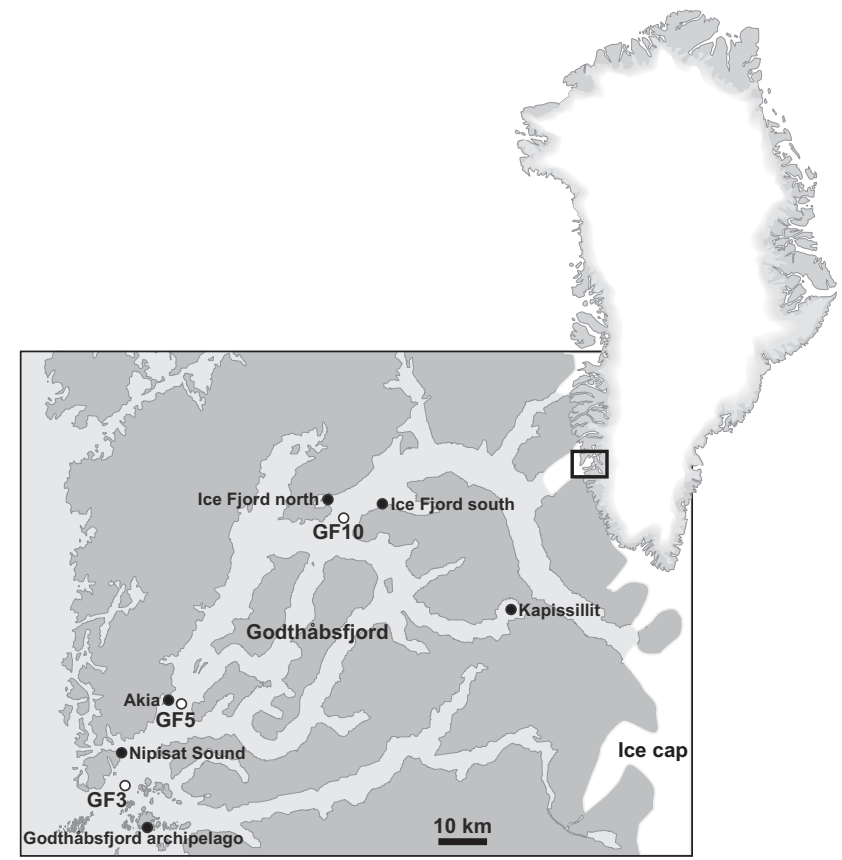

Fig. 1. Map of Godthåbsfjord with locations of shell collections (black circles) and water measurements (white circles).

\subsection{Calculation of predicted $\delta^{18} \mathrm{O}_{\mathrm{c}}$ values}

Many calcitic bivalve species precipitate their shells in oxygen isotopic equilibrium with the ambient water (Chauvaud et al., 2005; Freitas et al., 2012; Hickson et al., 1999), largely following the equation for inorganic calcite (Kim and O'Neil, 1997):

$1000 \ln \alpha_{\text {(calcite-water) }}=18.03\left(10^{3} T^{-1}\right)-32.42$.

For $M$. edulis calcite, a species-specific equation has been established, which is not statistically different from the above equilibrium equation (Wanamaker et al., 2007):

$1000 \ln \alpha_{\text {(calcite-water) }}=18.02\left(10^{3} T^{-1}\right)-31.84$. 
Table 2. PCR-based nuclear markers for Mytilus.

\begin{tabular}{|c|c|c|c|c|c|}
\hline \multirow[t]{2}{*}{ Marker } & \multirow[t]{2}{*}{ Enzyme } & \multicolumn{3}{|c|}{ Fragment sizes (bp) } & \multirow[t]{2}{*}{ References } \\
\hline & & M. edulis & M. trossulus & M. galloprovincialis & \\
\hline Mal-1 & SpeI & $\sim 650$ & $\sim 425 / 350 / 275$ & & Rawson et al. (1996b, 2001) \\
\hline ITS & HhaI & 200 & $200 / 450$ & 200 & Heath et al. (1995) \\
\hline Glu-5 & - & $350 / 380$ & 240 & $300 / 500$ & Rawson et al. (1996a) \\
\hline Me $15 / 16$ & - & 180 & 168 & 126 & Inoue et al. (1995), Kijewski et al. (2009) \\
\hline
\end{tabular}

A

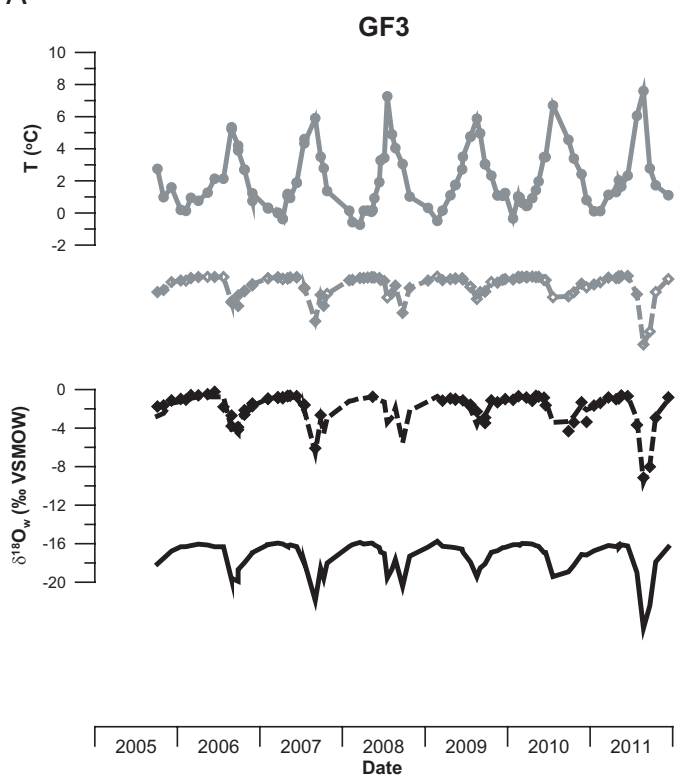

B<smiles>C=[SeH]</smiles>

Fig. 2. Environmental data at water monitoring locations. Solid grey circles and lines are temperature; grey diamonds and dashed lines are salinity. Black diamonds are measured $\delta^{18} \mathrm{O}_{\mathrm{w}}$ values; dashed black lines show $\delta^{18} \mathrm{O}_{\mathrm{w}}$ values calculated from the linear relationship between salinity and $\delta^{18} \mathrm{O}_{\mathrm{w}}$ values (Eq. 4). Solid black lines indicate $\delta^{18} \mathrm{O}_{\text {pred }}$ values based on temperature and $\delta^{18} \mathrm{O}_{\mathrm{w}}$ values, calculated according to Eq. (2).

In both equations $T$ is the temperature in $\mathrm{K}$ and $\alpha$ is the isotope fractionation factor:

$\alpha_{\mathrm{c}-\mathrm{w}}=\frac{\left(1000+\delta^{18} \mathrm{O}_{\mathrm{c}}(\text { VSMOW })\right)}{\left(1000+\delta^{18} \mathrm{O}_{\mathrm{w}}(\text { VSMOW } .)\right)}$

For calculation of predicted $\delta^{18} \mathrm{O}_{\mathrm{c}}\left(\delta^{18} \mathrm{O}_{\text {pred }}\right)$ values, we use the species-specific Eq. (2).

\subsection{Alignment of $\delta^{18} O_{\text {pred }}$ and $\delta^{18} O_{c}$ values}

In order to align measured $\delta^{18} \mathrm{O}_{\mathrm{c}}$ values with $\delta^{18} \mathrm{O}_{\text {pred }}$ values, seasonal shell $\delta^{18} \mathrm{O}_{\mathrm{c}}$ records were separated into calendar years, allowing for a growth cessation at the peak $\delta^{18} \mathrm{O}_{\mathrm{c}}$ value as well as at the summer low $\delta^{18} \mathrm{O}_{\mathrm{c}}$ value (Goewert et al., 2007; Goodwin et al., 2003; Versteegh et al., 2009). Peaks and troughs of the $\delta^{18} \mathrm{O}_{\text {pred }}$ and $\delta^{18} \mathrm{O}_{\mathrm{c}}$ records were first aligned, and subsequently the points in between, shifting the $\delta^{18} \mathrm{O}_{\mathrm{c}}$ values point-by-point along the time-axis, to match corresponding values on the $\delta^{18} \mathrm{O}_{\text {pred }}$ curve (Freitas et al., 2006; Goewert et al., 2007; Versteegh et al., 2010a).

\section{Results}

\subsection{Water data}

Water temperature varied between minima of around $-1{ }^{\circ} \mathrm{C}$ and maxima of 6 to $9^{\circ} \mathrm{C}$ in all three locations. Salinity and $\delta^{18} \mathrm{O}_{\mathrm{w}}$ values are close to those of full marine conditions ( 33.5 and $-0.7 \%$, respectively) during the first half of the year (January-June), and show sharp excursions towards much lower values during the following months. Salinity minimum values vary between $\sim 19$ at GF3 and GF5, down to 4.6 at GF10. Minimum $\delta^{18} \mathrm{O}_{\mathrm{w}}$ values show a similar behaviour with -9.1 and $-9.8 \%$, for GF3 and GF5 respectively, and a very low $-18.6 \%$ at GF10 (Fig. 2a-c). 


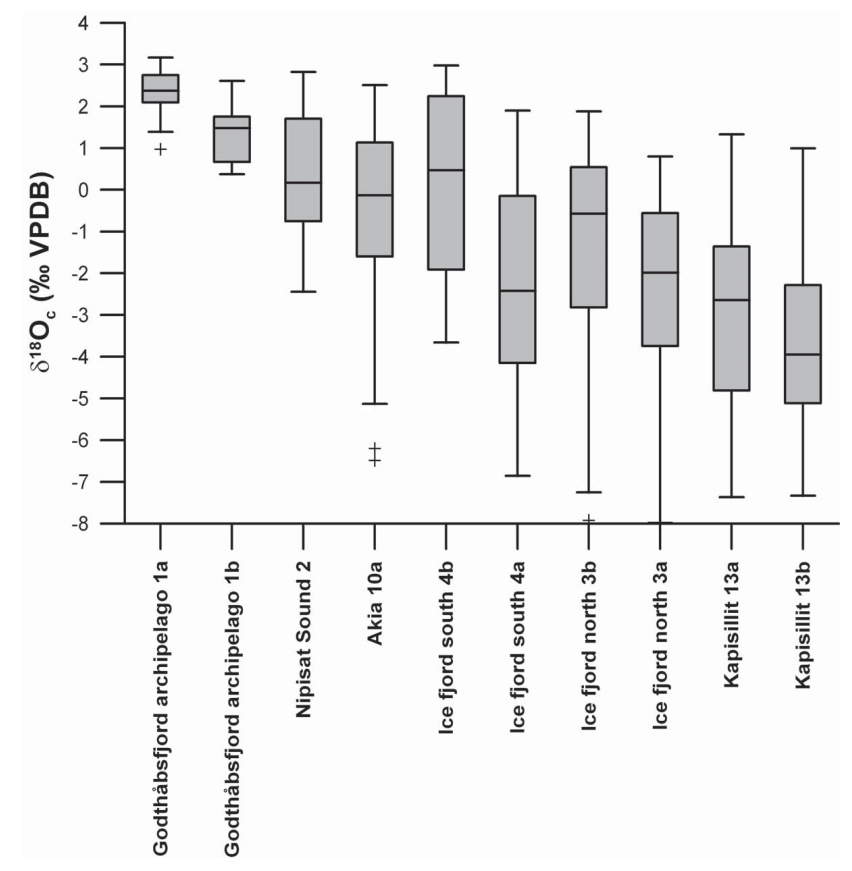

Fig. 3. Box and whisker diagram of $\delta^{18} \mathrm{O}$ values of all shells. Grey boxes are $50 \%$ of data, whiskers $25 \%$ of data each; outliers are indicated with + symbols. At the left side of the graph are the shells that were collected closest to the open ocean and show least influence of freshwater in their $\delta^{18} \mathrm{O}_{\mathrm{c}}$ values. At the right side are the shells collected closest to the glacier, with most profound freshwater influence on their $\delta^{18} \mathrm{O}_{\mathrm{c}}$ values.

\subsection{Measured $\delta^{18} \mathrm{O}_{\mathrm{c}}$ values in shells}

Microsampling of the 2 to 3 last growth increments, counted from the ventral margin, yielded between 14 and 40 samples per shell. Bulk shell composition is shown as the range of data in a box and whisker diagram (Fig. 3). Shell $\delta^{18} \mathrm{O}_{\mathrm{c}}$ values vary between 3.7 and $-8.0 \%$ (VPDB). In proximity of the glacier, seasonal $\delta^{18} \mathrm{O}_{\mathrm{c}}$ minima are $\sim 9.0 \%$ o lower than nearer the coast $(-8.0 \%$ in Ice Fjord north $3 \mathrm{a}$ vs. $1.0 \%$ in Godthåbsfjord Archipelago 1a); maximum $\delta^{18} \mathrm{O}_{\mathrm{c}}$ values differ by only $2.9 \%$ ( $0.8 \%$ in Ice Fjord north $3 \mathrm{a}$ vs. $3.7 \%$ in Godthåbsfjord Archipelago 1a; Fig. 3).

Shell $\delta^{18} \mathrm{O}_{\mathrm{c}}$ values along the growth axis are plotted as a function of distance from the ventral margin. The ventral margin represents the shell material precipitated immediately before shell collection. The distance axis is therefore reversed. These $\delta^{18} \mathrm{O}_{\mathrm{c}}$ records show typical periodic patterns of seasonal growth, influenced by seasonally varying temperature and $\delta^{18} \mathrm{O}_{\mathrm{w}}$ values. Winters are represented by peaks in $\delta^{18} \mathrm{O}_{\mathrm{c}}$ values because of low temperatures and low meltwater input. Summers are troughs in $\delta^{18} \mathrm{O}_{\mathrm{c}}$ values because of higher temperatures and higher meltwater input (see also Discussion). Winter peaks are sharper than summer troughs in $\delta^{18} \mathrm{O}_{\mathrm{w}}$ values, and are therefore likely truncated by sea- sonal growth cessation (Fig. 4a-j) (Goewert et al., 2007; Goodwin et al., 2003).

Conspicuous dark lines (under reflected light) within the shells correspond to a slowing of growth prior to growth cessation, and roughly correspond to winter growth cessations in the $\delta^{18} \mathrm{O}_{\mathrm{c}}$ records (Fig. $4 \mathrm{a}-\mathrm{j}$ ). The number of years counted by dark growth lines and the number of $\delta^{18} \mathrm{O}_{\mathrm{c}}$ peaks are the same in all shells, except Ice Fjord north 3a, which has insufficient resolution to discern annual cycles, and Kapisillit 13a, which appears to have one extra growth cessation during the summer of 2008 (Fig. 4g and i). Lighter growth lines than the annual ones can be seen in several specimens (Godthåbsfjord archipelago $1 \mathrm{a} \& 1 \mathrm{~b}$, Ice Fjord south $4 \mathrm{~b}$, Ice Fjord north $3 \mathrm{~b}$, Kapisillit 13a; Fig. 4a, b, f, h and i). These lighter lines apparently correspond with troughs in the $\delta^{18} \mathrm{O}_{\mathrm{c}}$ records, and are probably caused by an additional cessation of growth during maximum meltwater input (see Discussion). Using growth lines and $\delta^{18} \mathrm{O}_{\mathrm{c}}$ values, calendar years can be assigned in all but one shell (Ice Fjord north 3a; Fig. 4g). This specimen is therefore excluded from subsequent analysis.

\section{Discussion}

\subsection{Relationship $\delta^{18} \mathrm{O}_{w}$-salinity}

Regression analysis yields a linear relationship between $\delta^{18} \mathrm{O}_{\mathrm{w}}$ values and salinity:

$\delta^{18} \mathrm{O}_{\mathrm{w}}=0.631 \cdot S-21.84$,

where $S$ is salinity $\left(R^{2}=0.9778 ; p<0.0005 ; n=202\right)$. An ANOVA showed there is no significant difference in regression coefficient between locations (Fig. 5). From this relationship it follows that glacier meltwater has a $\delta^{18} \mathrm{O}_{\mathrm{w}}$ value of $-21.8 \%$ (VSMOW) and seawater has a salinity of $\sim 33.5$ and a $\delta^{18} \mathrm{O}_{\mathrm{w}}$ value of $\sim-0.7 \%$ (VSMOW). From the linear mixing of freshwater and seawater, it follows that there is a direct and simple relationship between glacier meltwater amounts and salinity $\left(\delta^{18} \mathrm{O}_{\mathrm{w}}\right)$ at any point in the fjord.

\subsection{Equilibrium precipitation of calcite}

Although it is known from experiments that M. edulis precipitates its shell in oxygen isotopic equilibrium with the ambient water (see Wanamaker et al., 2006, 2007), we aimed to confirm this for the specimens presented here in a field setting. A valid approach is to compare the $\delta^{18} \mathrm{O}_{\mathrm{c}}$ value of the ventral margin with $\delta^{18} \mathrm{O}_{\text {pred }}$ values calculated from $\delta^{18} \mathrm{O}_{\mathrm{w}}$ values and temperature on the date of shell collection (Versteegh et al., 2010a). Five shells were selected that were collected closest to the water monitoring locations. $\delta^{18} \mathrm{O}_{\text {pred }}$ values were calculated using Eq. (2) and $\delta^{18} \mathrm{O}_{\mathrm{w}}$ values calculated from salinity (Eq. 4). $\delta^{18} \mathrm{O}_{\text {pred }}$ and $\delta^{18} \mathrm{O}_{\mathrm{c}}$ values are presented in Table 3. There is a good correspondence between $\delta^{18} \mathrm{O}_{\text {pred }}$ and $\delta^{18} \mathrm{O}_{\mathrm{c}}$ values. They differ only by 0.1 to $0.3 \%$, 

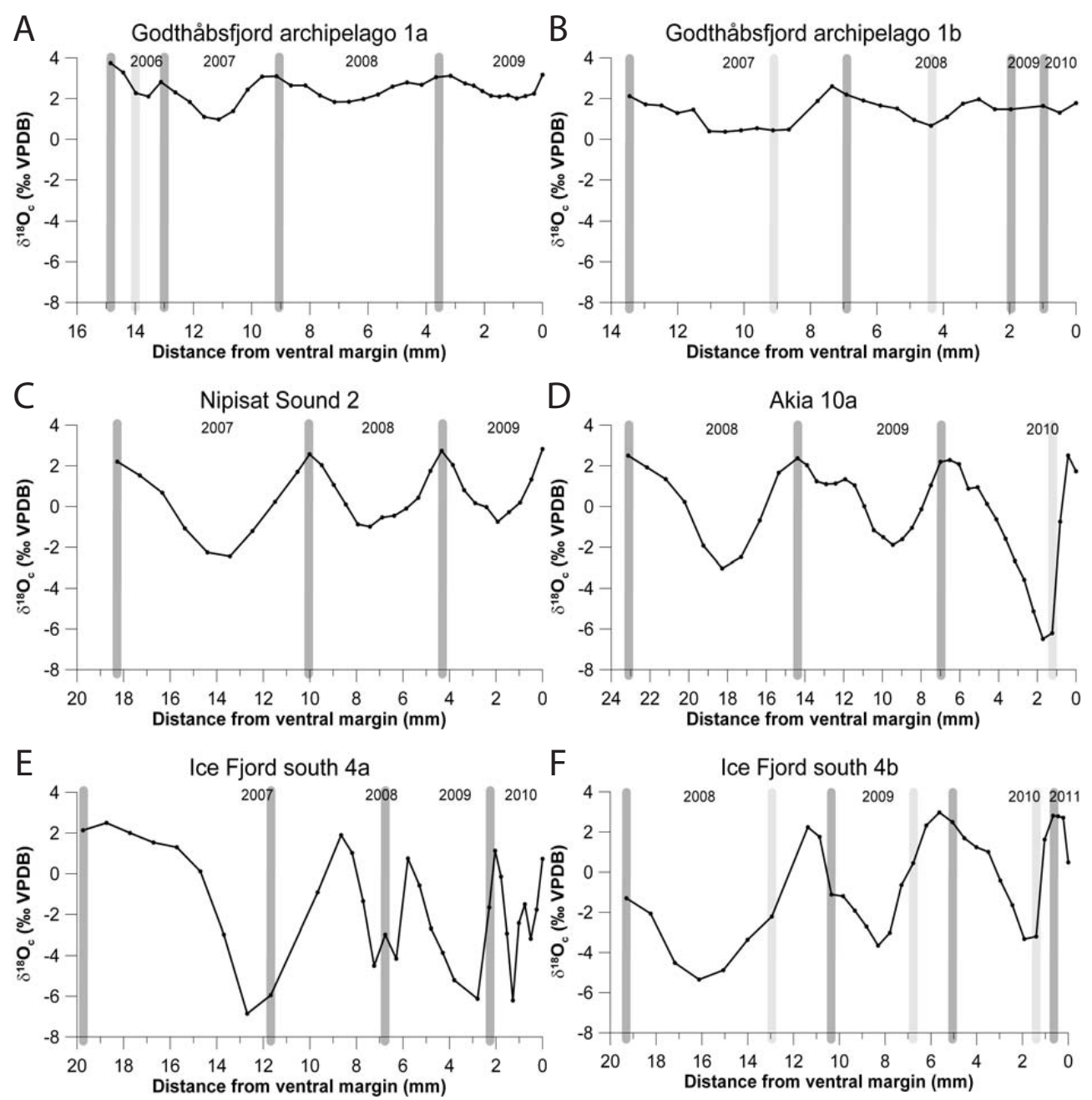

F Ice Fjord south 4b
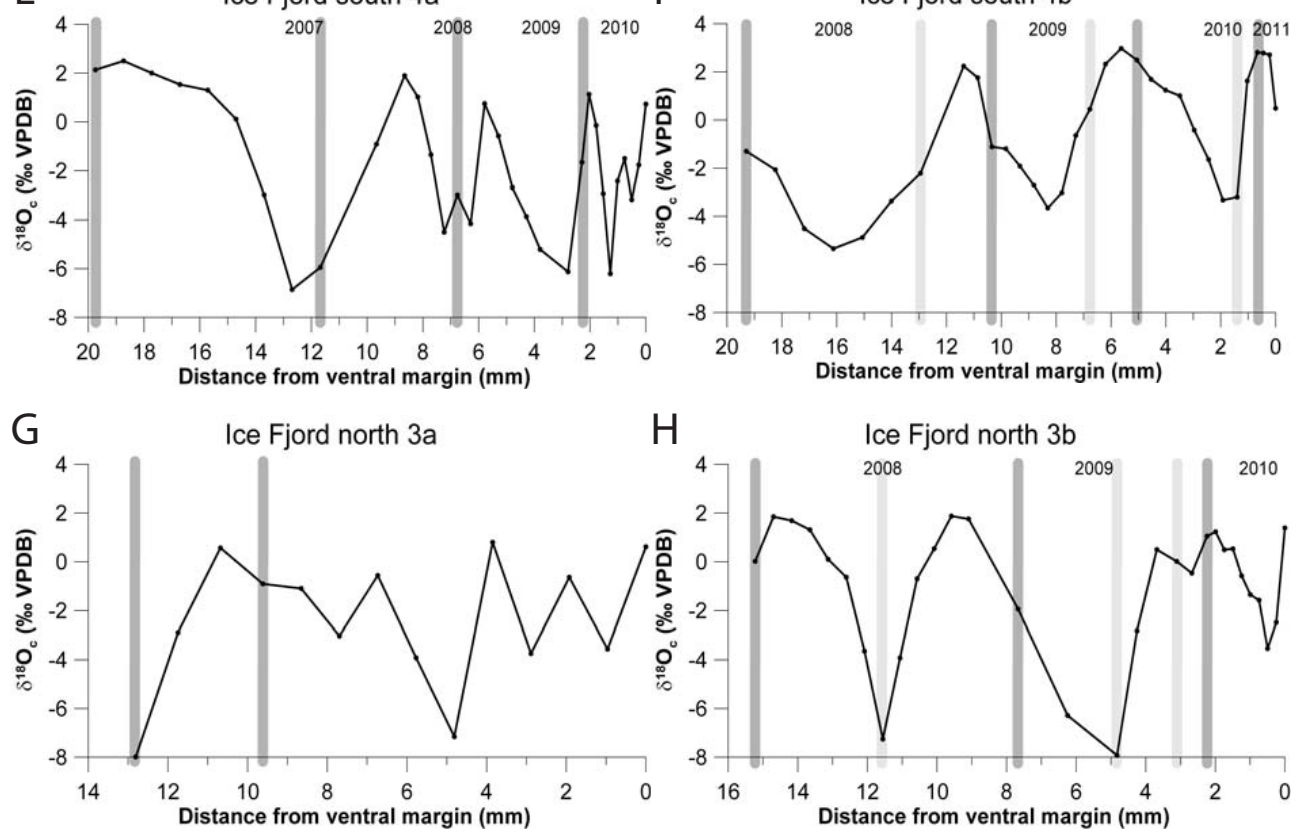

$\mathrm{H} \quad$ Ice Fjord north 3b
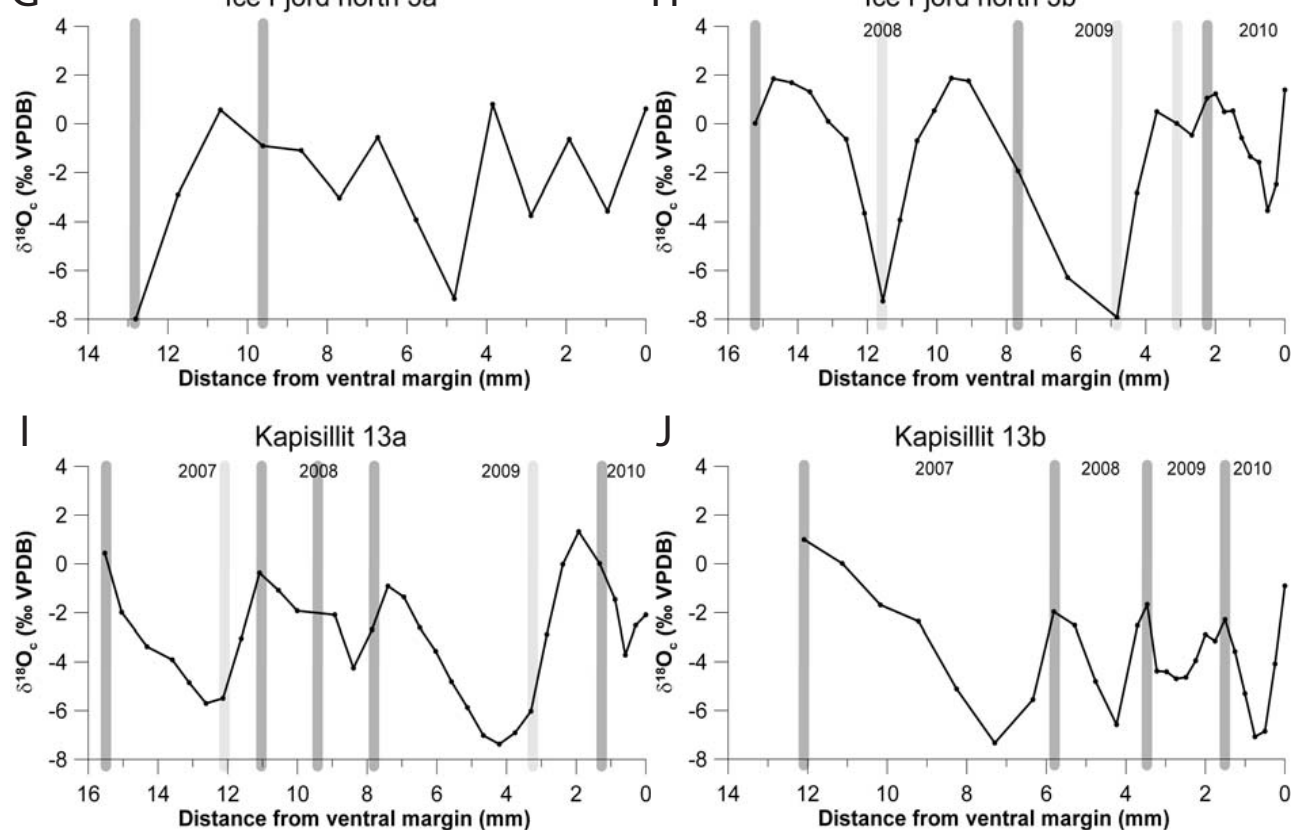

J Kapisillit 13b
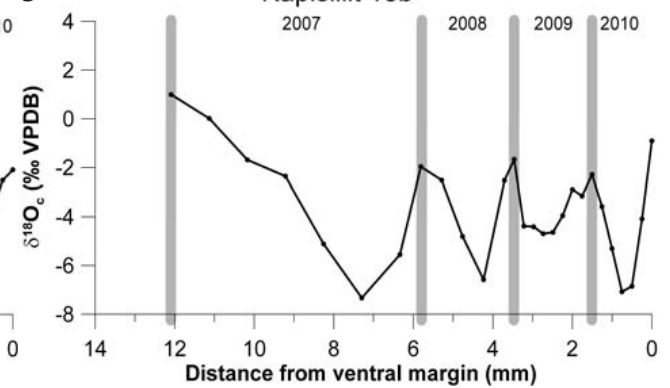

Fig. 4. Seasonal $\delta^{18} \mathrm{O}_{\mathrm{c}}$ graphs of shells. In dark grey distinct dark growth lines (expected to be annual growth cessations) are indicated, in light grey less profound dark lines observed in the shell. 


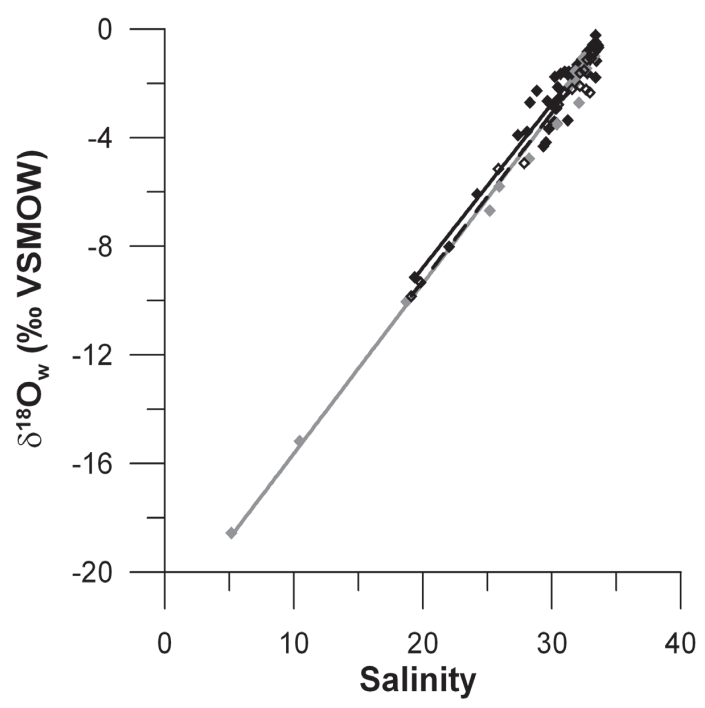

Fig. 5. Scatter plot showing the relationship between $\delta^{18} \mathrm{O}_{\mathrm{w}}$ values and salinity for the three sampling locations: $\delta^{18} \mathrm{O}_{\mathrm{w}}=0.631$. $S-21.84\left(R^{2}=0.9778 ; p<0.0005 ; n=202\right)$. Black diamonds and solid line are GF3; open diamonds and black dashed line are GF5; grey diamonds and solid line are GF10.

with the exception of shell Ice Fjord north $3 b$, which differs by $0.7 \%$ ofrom $\delta^{18} \mathrm{O}_{\text {pred }}$ values. It is likely that this shell did not precipitate any calcite immediately before it was collected.

\subsection{Predicted and measured shell $\delta^{18} \mathrm{O}_{\mathrm{c}}$}

$\delta^{18} \mathrm{O}_{\text {pred }}$ values were calculated using Eq. (2), the seasonal temperature record, and $\delta^{18} \mathrm{O}_{\mathrm{w}}$ values based on salinity (Eq. 4). The influence of $\delta^{18} \mathrm{O}_{\mathrm{w}}$ on $\delta^{18} \mathrm{O}_{\text {pred }}$ values is dominant over that of temperature, resulting in $\delta^{18} \mathrm{O}_{\text {pred }}$ curves that are similar in shape to $\delta^{18} \mathrm{O}_{\mathrm{w}}$ curves (Fig. 2a-c).

Seasonal $\delta^{18} \mathrm{O}_{\mathrm{c}}$ records of the five shells selected above can now be compared with seasonal $\delta^{18} \mathrm{O}_{\text {pred }}$ values. As the shell $\delta^{18} \mathrm{O}_{\mathrm{c}}$ peaks are sharper than the $\delta^{18} \mathrm{O}_{\text {pred }}$ records, it is likely that shells cease growing during winter. Similarly, during several summer seasons, the shell $\delta^{18} \mathrm{O}_{\mathrm{c}}$ records appear "dampened" and do not record low $\delta^{18} \mathrm{O}_{\mathrm{w}}$ values (see further discussion below), suggesting an additional summer growth cessation. The $\delta^{18} \mathrm{O}_{\text {pred }}$ and $\delta^{18} \mathrm{O}_{\mathrm{c}}$ records were aligned by first matching peaks and troughs, and subsequent point-bypoint time-axis shifting (Freitas et al., 2006; Goewert et al., 2007; Versteegh et al., 2010a).

At the locations GF3 and GF5, $\delta^{18} \mathrm{O}_{\text {pred }}$ and $\delta^{18} \mathrm{O}_{\mathrm{c}}$ values correspond well, with the shells faithfully recording almost the entire range of $\delta^{18} \mathrm{O}_{\text {pred }}$ values. In the shell Nipisat Sound 2, the meltwater peaks of 2007 and 2008 do not seem to be recorded entirely, probably due to time-averaging within one shell powder sample (Goodwin et al., 2003). The same is true for the very low $\delta^{18} \mathrm{O}_{\text {pred }}$ values at GF5 and in the shell Akia 10a during 2010.
This difference of up to $1.9 \%$ can alternatively be caused by a summer growth cessation, occurring when ambient water becomes too fresh for the mussels to thrive (Qiu et al., 2002). This certainly seems to be the case in the three shells collected near GF10, and probably in the Akia 10a shell as well. None of them recorded the very low $\delta^{18} \mathrm{O}_{\mathrm{w}}$ values during 2010. Many shells also show a faint dark line (slow growth prior to growth cessation) during periods of low $\delta^{18} \mathrm{O}_{\mathrm{c}}$ values (Fig. $4 \mathrm{a}-\mathrm{j}$ ). It is known that marine bivalves, including $M$. edulis, have a reduced size and growth rate in low-salinity conditions (Schöne et al., 2003; Westerbom et al., 2002), and that salinities lower than 9.6 are lethal to the mussels within 10 days (Almada-Villela, 1984; Qiu et al., 2002). In response to a sudden drop in salinity, M. edulis withdraws its mantle and siphons, and closes its valves (Qiu et al., 2002). It is likely that the mussels in Godthåbsfjord show this behaviour when exposed to very low salinities and as such cease growing and fail to record large meltwater pulses. $\delta^{18} \mathrm{O}_{\mathrm{c}}$ values suggest that the threshold salinity value for shell growth is at $\sim 19$. However, the abrupt decrease in salinity $/ \delta^{18} \mathrm{O}_{\mathrm{w}}$ values at the beginning of the melt season, combined with the limitations given by the resolution of data, makes it difficult to establish a precise threshold for growth.

\section{Conclusions}

Observations on salinity and $\delta^{18} \mathrm{O}_{\mathrm{w}}$ values show that there is linear mixing of seawater and meltwater in Godthåbsfjord, implying that the meltwater contributions and $\delta^{18} \mathrm{O}_{\mathrm{w}}$ values follow a simple and predictable relationship at any location in the fjord. This indicates that glacier meltwater is the dominant source of freshwater in the fjord system.

Our results corroborate previous findings that M. edulis precipitates shell calcite in oxygen isotopic equilibrium with the ambient water, not only under controlled laboratory conditions (Wanamaker et al., 2006, 2007), but also under natural conditions. Oscillating $\delta^{18} \mathrm{O}_{\mathrm{w}}$ values in Godthåbsfjord are faithfully recorded, at least at salinities $\sim>19$, below which shell growth apparently ceases.

Comparison of $\delta^{18} \mathrm{O}_{c}$ values and growth lines, visible in shell cross-section, shows that conspicuous dark lines are winter growth cessations, whereas growth cessations caused by low salinities are visible as a thinner and lighter growth lines within annual bands.

We conclude that this species can be suitable for reconstructing past meltwater amounts in ice sheet influenced fjords, and may offer an opportunity to investigate GrIS melting during previous Holocene warm periods. Care has to be taken, however, that individuals are used that lived not too close to a glacier, but rather in the centre or mouth of a fjord, so the full amplitude of local $\delta^{18} \mathrm{O}_{\mathrm{w}}$ variations is captured. 
Table 3. Comparison of ventral margin $\delta^{18} \mathrm{O}_{\mathrm{c}}$ and $\delta^{18} \mathrm{O}_{\text {pred }}$ values.

\begin{tabular}{lllcc}
\hline Sample ID & Collection date & Station & $\delta^{18} \mathrm{O}_{\text {pred }}(\% \circ$ VPDB $)$ & Ventral margin $\delta^{18} \mathrm{O}_{\mathrm{c}}(\% \circ \mathrm{VPDB})$ \\
\hline Nipisat Sound 2 & $14 / 05 / 2010$ & GF3 & 2.50 & 2.82 \\
Akia 10a & $02 / 06 / 2011$ & GF5 & 1.85 & 1.73 \\
Ice Fjord north 3b & $01 / 06 / 2011$ & GF10 & 0.67 & 1.39 \\
Ice Fjord south 4a & $01 / 06 / 2011$ & GF10 & 0.67 & 0.73 \\
Ice Fjord south 4b & $01 / 06 / 2011$ & GF10 & 0.67 & 0.49 \\
\hline
\end{tabular}
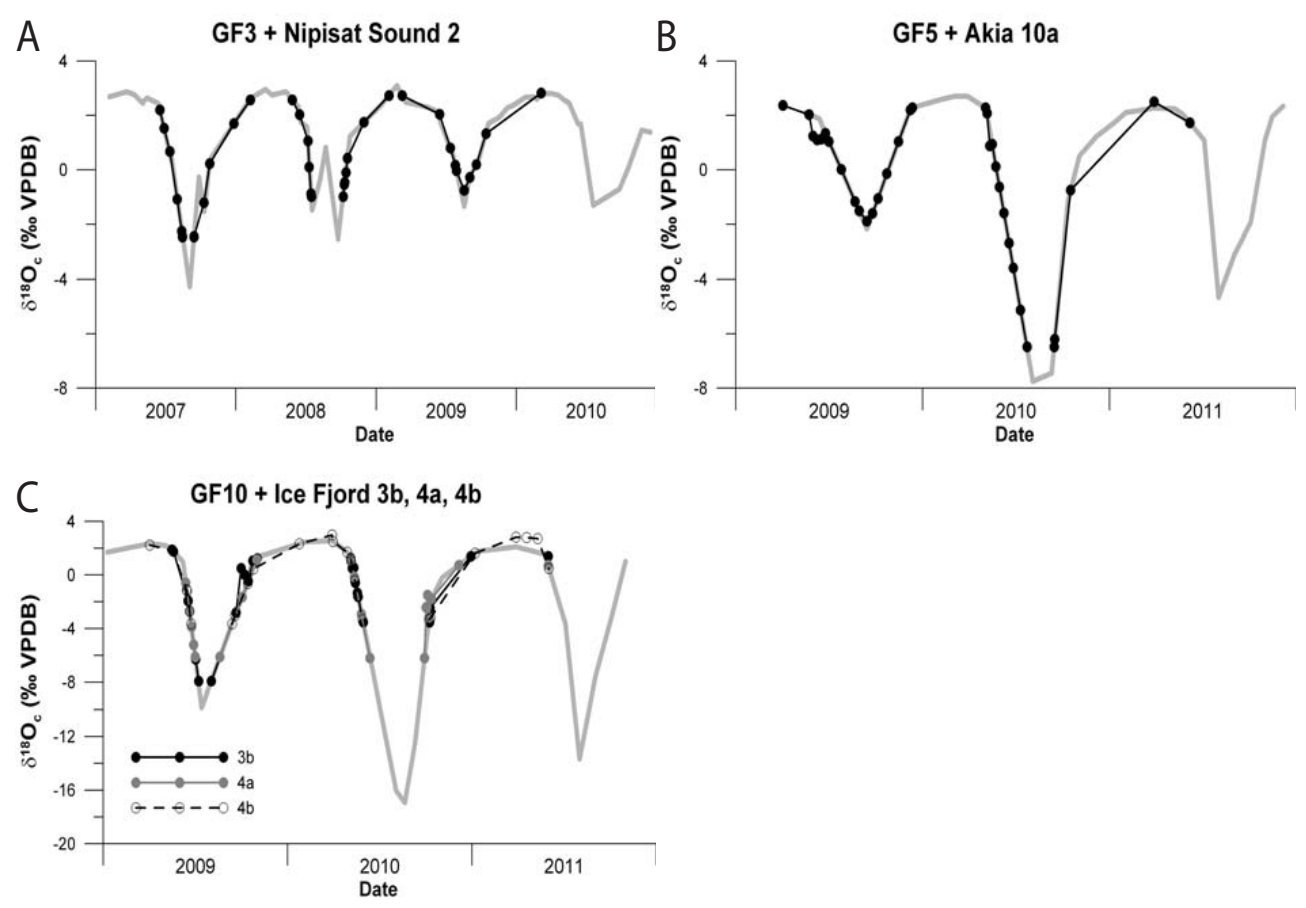

Fig. 6. Comparison of $\delta^{18} \mathrm{O}_{\text {pred }}$ and $\delta^{18} \mathrm{O}_{\mathrm{c}}$ values for three different sites. In addition to a winter growth cessation that is visible in most shells, a summer growth cessation appears to occur when $\delta^{18} \mathrm{O}_{\mathrm{w}}$ values (i.e. salinity) become too low.

Future research will focus on expanding the geographical and temporal range of these shell $\delta^{18} \mathrm{O}_{\mathrm{c}}$ records, by sampling modern mussels from other fjords in Greenland along a south-north gradient. In addition shells will be sampled from raised shorelines (6000-8000 BP) and archaeological shell middens from prehistoric settlements in Greenland.

Acknowledgements. We would like to thank Suzanne Ankerstjerne (Iowa State University) and Yan Gao (University of Reading) for their help with carbonate oxygen isotope analyses. We also thank Stuart Robinson and Dorinda Ostermann (University College London), and Hubert Vonhof and Suzan Warmerdam (VU University Amsterdam) for making available their micromills. T. Juul-Pedersen, K. Arendt, T. Krogh, D. Søgård and W. Martinsen (Greenland Institute of Natural Resources) are all thanked for their help with hydrographic measurements. The study was financially supported by the Greenland Climate Research Centre, the Danish Ministry of the Environment (Dancea), Aarhus University, the Commission for Scientific Research in Greenland, Canada
Excellence Research Chair program, the Ministry of Education, Research and Nordic cooperation (IIN) and Aage V Jensen Charity Foundation, and is a part of the Greenland Ecosystem Monitoring program (www.g-e-m.dk).

Edited by: A. Shemesh

\section{References}

Abell, P. I. and Hoelzmann, P.: Holocene palaeoclimates in northwestern Sudan: stable isotope studies on molluscs, Global Planet. Change, 26, 1-12, doi:10.1016/S0921-8181(00)00030-8, 2000.

Alley, R. B., Andrews, J. T., Brigham-Grette, J., Clarke, G. K. C., Cuffey, K. M., Fitzpatrick, J. J., Funder, S., Marshall, S. J., Miller, G. H., Mitrovica, J. X., Muhs, D. R., Otto-Bliesner, B. L., Polyak, L., and White, J. W. C.: History of the Greenland Ice Sheet: paleoclimatic insights, Quatern. Sci. Rev., 29, 1728-1756, doi:10.1016/j.quascirev.2010.02.007, 2010. 
Almada-Villela, P. C.: The Effects of Reduced Salinity on the Shell Growth of Small Mytilus Edulis, J. Mar. Biol. Assoc. UK, 64, 171-182, doi:10.1017/S0025315400059713, 1984.

Andresen, C. S., Straneo, F., Ribergaard, M. H., Bjork, A. A., Andersen, T. J., Kuijpers, A., Norgaard-Pedersen, N., Kjaer, K. H., Schjoth, F., Weckstrom, K., and Ahlstrom, A. P.: Rapid response of Helheim Glacier in Greenland to climate variability over the past century, Nature Geosci., 5, 37-41, doi:10.1038/ngeo1349, 2012.

Applegate, P. J., Kirchner, N., Stone, E. J., Keller, K., and Greve, R.: An assessment of key model parametric uncertainties in projections of Greenland Ice Sheet behavior, The Cryosphere, 6, 589606, doi:10.5194/tc-6-589-2012, 2012.

Box, J. E., Bromwich, D. H., Veenhuis, B. A., Bai, L.-S., Stroeve, J. C., Rogers, J. C., Steffen, K., Haran, T., and Wang, S.-H.: Greenland Ice Sheet Surface Mass Balance Variability (1988-2004) from Calibrated Polar MM5 Output, J. Climate, 19, 2783-2800, doi:10.1175/jcli3738.1, 2006.

Carré, M., Bentaleb, I., Blamart, D., Ogle, N., Cardenas, F., Zevallos, S., Kalin, R. M., Ortlieb, L., and Fontugne, M.: Stable isotopes and sclerochronology of the bivalve Mesodesma donacium: Potential application to Peruvian paleoceanographic reconstructions, Palaeogeogr. Palaeoclimatol. Palaeoecol., 228, 4-25, 2005.

Chauvaud, L., Lorrain, A., Dunbar, R., Paulet, Y.-M., Thouzeau, G., Jean, F., Guarini, J.-M., and Mucciarone, D.: The shell of the Great Scallop Pecten maximus as a high-frequency archive of paleoenvironmental changes, Geochem. Geophy. Geosy., 6, Q08001, doi:10.1029/2004GC000890, 2005.

Coplen, T. B.: Reporting of stable hydrogen, carbon, and oxygen isotopic abundances, Pure Appl. Chem., 88, 273-276, 1994.

Doherty, S., Gosling, E., and Was, A.: Bivalve ligament - a new source of DNA for historical studies, Aquat. Biol., 1, 161-165, doi:10.3354/ab00020, 2007.

Donner, J. and Nord, A. G.: Carbon and oxygen stable isotope values in shells of Mytilus edulis and Modiolus modiolus from Holocene raised beaches at the outer coast of the Varanger Peninsula, North Norway, Palaeogeogr. Palaeoclimatol. Palaeoecol., 56, 35-50, doi:10.1016/0031-0182(86)90106-9, 1986.

Freitas, P. S., Clarke, L. J., Kennedy, H., Richardson, C. A., and Abrantes, F.: Environmental and biological controls on elemental $(\mathrm{Mg} / \mathrm{Ca}, \mathrm{Sr} / \mathrm{Ca}$ and $\mathrm{Mn} / \mathrm{Ca})$ ratios in shells of the king scallop Pecten maximus, Geochim. Cosmochim. Acta, 70, 5119-5133, doi:10.1016/j.gca.2006.07.029, 2006.

Freitas, P. S., Clarke, L. J., Kennedy, H., and Richardson, C. A.: The potential of combined $\mathrm{Mg} / \mathrm{Ca}$ and $\delta^{18} \mathrm{O}$ measurements within the shell of the bivalve Pecten maximus to estimate seawater $\delta^{18} \mathrm{O}$ composition, Chem. Geol., 291, 286-293, doi:10.1016/j.chemgeo.2011.10.023, 2012.

Goewert, A., Surge, D., Carpenter, S. J., and Downing, J.: Oxygen and carbon isotope ratios of Lampsilis cardium (Unionidae) from two streams in agricultural watersheds of Iowa, USA, Palaeogeogr. Palaeoclimatol. Palaeoecol., 252, 637-648, doi:10.1016/j.palaeo.2007.06.002, 2007.

Goodfriend, G. A. and Ellis, G. L.: Stable carbon and oxygen isotopic variations in modern Rabdotus land snail shells in the southern Great Plains, USA, and their relation to environment, Geochim. Cosmochim. Acta, 66, 1987-2002, doi:10.1016/S0016-7037(02)00824-4, 2002.
Goodwin, D. H., Schöne, B. R., and Dettman, D. L.: Resolution and fidelity of oxygen isotopes as paleotemperature proxies in bivalve mollusk shells: models and observations, Palaios, 18, 110-125, doi:10.1669/08831351(2003) $18<110$ :RAFOOI $>2.0$. CO;2, 2003.

Halfar, J., Steneck, R. S., Joachimski, M., Kronz, A., and Wanamaker, A. D., Jr.: Coralline red algae as high-resolution climate recorders, Geology, 36, 463-466, doi:10.1130/g24635a.1, 2008.

Hanna, E., Huybrechts, P., Cappelen, J., Steffen, K., Bales, R. C., Burgess, E., McConnell, J. R., Peder Steffensen, J., Van den Broeke, M., Wake, L., Bigg, G., Griffiths, M., and Savas, D.: Greenland Ice Sheet surface mass balance 1870 to 2010 based on Twentieth Century Reanalysis, and links with global climate forcing, J. Geophys. Res., 116, D24121, doi:10.1029/2011jd016387, 2011.

Heath, D. D., Rawson, P. D., and Hilbish, T. J.: PCR-based nuclear markers identify alien blue mussel (Mytilus spp.) genotypes on the west coast of Canada, 12, National Research Council of Canada, Ottawa, ON, Canada, 1995.

Hickson, J. A., Johnson, A. L. A., Heaton, T. H. E., and Balson, P. S.: The shell of the Queen Scallop Aequipecten opercularis (L.) as a promising tool for palaeoenvironmental reconstruction: evidence and reasons for equilibrium stable-isotope incorporation, Palaeogeogr. Palaeoclimatol. Palaeoecol., 154, 325-337, doi:10.1016/S0031-0182(99)00120-0, 1999.

Hjort, C. and Funder, S.: The subfossil occurrence of Mytilus edulis L. in central East Greenland, Boreas, 3, 23-33, doi:10.1111/j.1502-3885.1974.tb00664.x, 1974.

Howat, I. M., Joughin, I., Tulaczyk, S., and Gogineni, S.: Rapid retreat and acceleration of Helheim Glacier, east Greenland, Geophys. Res. Lett., 32, L22502, doi:10.1029/2005GL024737, 2005.

Ingram, B. L., Conrad, M. E., and Ingle, J. C.: Stable isotope and salinity systematics in estuarine waters and carbonates: San Francisco Bay, Geochim. Cosmochim. Acta, 60, 455-467, doi:10.1016/0016-7037(95)00398-3, 1996.

Inoue, K., Waite, J. H., Matsuoka, M., Odo, S., and Harayama, S.: Interspecific Variations in Adhesive Protein Sequences of Mytilus edulis, M. galloprovincialis, and M. trossulus, Biol. Bull., 189, 370-375, 1995.

IPCC: Climate Change 2007: The physical science basis. Contribution of working group I to the fourth assessment - Report of the Intergovernmental Panel on Climate Change, Cambridge University Press, Cambridge, 996, 2007.

Israelson, C., Buchardt, B., Funder, S., and Hubberten, H. W.: Oxygen and carbon isotope composition of Quaternary bivalve shells as a water mass indicator: Last interglacial and Holocene, East Greenland, Palaeogeogr. Palaeoclimatol. Palaeoecol., 111, 119124, doi:10.1016/0031-0182(94)90351-4, 1994.

Jones, D. S. and Quitmyer, I. R.: Marking time with bivalve shells: Oxygen Isotopes and season of annual increment formation, Palaios, 11, 340-346, 1996.

Kaandorp, R. J. G., Vonhof, H. B., Del Busto, C., Wesselingh, F. P., Ganssen, G. M., Marmol, A. E., Romero Pittman, L., and van Hinte, J. E.: Seasonal stable isotope variations of the modern Amazonian freshwater bivalve Anodontites trapesialis, Palaeogeogr. Palaeoclimatol. Palaeoecol., 194, 339-354, doi:10.1016/S0031-0182(03)00332-8, 2003.

Khim, B.-K.: Stable isotope profiles of Serripes groenlandicus shells. I. Seasonal and interannual variations of Alaskan Coastal 
Water in the Bering and Chukchi Seas, Geosciences Journal, 6, 257-267, doi:10.1007/BF03020611, 2002.

Kijewski, T., Wijsman, J. W. M., Hummel, H., and Wenne, R.: Genetic composition of cultured and wild mussels Mytilus from The Netherlands and transfers from Ireland and Great Britain, Aquaculture, 287, 292-296, doi:10.1016/j.aquaculture.2008.10.048, 2009.

Kim, S.-T. and O'Neil, J. R.: Equilibrium and nonequilibrium oxygen isotope effects in synthetic carbonates, Geochim. Cosmochim. Acta, 61, 3461-3475, doi:10.1016/S00167037(97)00169-5, 1997.

Krabill, W., Abdalati, W., Frederick, E., Manizade, S., Martin, C., Sonntag, J., Swift, R., Thomas, R., Wright, W., and Yungel, J.: Greenland Ice Sheet: High-Elevation Balance and Peripheral Thinning, Science, 289, 428-430, doi:10.1126/science.289.5478.428, 2000.

McDonald, J. H., Seed, R., and Koehn, R. K.: Allozymes and morphometric characters of three species of Mytilus in the Northern and Southern Hemispheres, Mar. Biol., 111, 323-333, doi:10.1007/bf01319403, 1991.

McGovern, T. H., Amorosi, T., Perdikaris, S., and Woollett, J.: Vertebrate Zooarchaeology of Sandnes V51: Economic Change at a Chieftain's Farm in West Greenland, Arctic Anthropology, 33, 94-121, 1996.

Mortensen, J., Lennert, K., Bendtsen, J., and Rysgaard, S.: Heat sources for glacial melt in a sub-Arctic fjord (Godthåbsfjord) in contact with the Greenland Ice Sheet, J. Geophys. Res., 116, C01013, doi:10.1029/2010jc006528, 2011.

Price, S. F., Payne, A. J., Howat, I. M., and Smith, B. E.: Committed sea-level rise for the next century from Greenland ice sheet dynamics during the past decade, P. Natl. Acad. Sci. USA, 108, 8978-8983, doi:10.1073/pnas.1017313108, 2011.

Qiu, J.-W., Tremblay, R., and Bourget, E.: Ontogenetic changes in hyposaline tolerance in the mussels Mytilus edulis and M. trossulus: implications for distribution, Mar. Ecol. Prog. Ser., 228, 143152, doi:10.3354/meps228143, 2002.

Rawson, P. D., Joyner, K. L., Meetze, K., and Hilbish, T. J.: Evidence for intragenic recombination within a novel genetic marker that distinguishes mussels in the Mytilus edulis species complex, Heredity, 77, 599-607, doi:10.1038/hdy.1996.187, 1996a.

Rawson, P. D., Secor, C. L., and Hilbish, T. J.: The Effects of Natural Hybridization on the Regulation of Doubly Uniparental mtDNA Inheritance in Blue Mussels (Mytilus spp.), Genetics, 144, 241-248, 1996 b.

Rawson, P. D., Hayhurst, S., and Vanscoyoc, B.: Species composition of blue mussel populations in the northeastern Gulf of Maine, J. Shellfish Res., 20, 31-38, 2001.

Richardson, C. A., Seed, R., and Naylor, E.: Use of internal growth bands for measuring individual and population growth rates in Mytilus edulis from offshore production platforms, Mar. Ecol. Prog. Ser., 66, 259-265, 1990.

Richter, A., Rysgaard, S., Dietrich, R., Mortensen, J., and Petersen, D.: Coastal tides in West Greenland derived from tide gauge records, Ocean Dynam., 61, 39-49, doi:10.1007/s10236-0100341-z, 2011.

Riginos, C. and Cunningham, C. W.: Invited review: Local adaptation and species segregation in two mussel (Mytilus edulis $\times$ Mytilus trossulus) hybrid zones, Mol. Ecol., 14, 381400, doi:10.1111/j.1365-294X.2004.02379.x, 2005.
Rignot, E. and Kanagaratnam, P.: Changes in the Velocity Structure of the Greenland Ice Sheet, Science, 311, 986-990, doi:10.1126/science.1121381, 2006.

Santos, S., Cardoso, J., Borges, V., Witbaard, R., Luttikhuizen, P., and van der Veer, H.: Isotopic fractionation between seawater and the shell of Scrobicularia plana (Bivalvia) and its application for age validation, Mar. Biol., 159, 601-611, doi:10.1007/s00227011-1838-9, 2012.

Schöne, B. R., Flessa, K. W., Dettman, D. L., and Goodwin, D. H.: Upstream dams and downstream clams: growth rates of bivalve mollusks unveil impact of river management on estuarine ecosystems (Colorado River Delta, Mexico), Estuar. Coast. Shelf. Sci., 58, 715-726, doi:10.1016/S0272-7714(03)00175-6, 2003.

Schöne, B. R., Fiebig, J., Pfeiffer, M., Gleb, R., Hickson, J., Johnson, A. L. A., Dreyer, W., and Oschmann, W.: Climate records from a bivalved Methuselah (Arctica islandica, Mollusca; Iceland), Palaeogeogr. Palaeoclimatol. Palaeoecol., 228, 130-148, doi:10.1016/j.palaeo.2005.03.049, 2005.

Stevens, R. E., Metcalfe, S. E., Leng, M. J., Lamb, A. L., Sloane, H. J., Naranjo, E., and González, S.: Reconstruction of late Pleistocene climate in the Valsequillo Basin (Central Mexico) through isotopic analysis of terrestrial and freshwater snails, Palaeogeogr. Palaeoclimatol. Palaeoecol., 319-320, 1627, doi:10.1016/j.palaeo.2011.12.012, 2012.

Swart, P. K.: Carbon and oxygen isotope fractionation in scleractinian corals: a review, Earth-Sci. Rev., 19, 51-80, doi:10.1016/0012-8252(83)90076-4, 1983.

Varvio, S. L., Koehn, R. K., and Väinölä, R.: Evolutionary genetics of the Mytilus edulis complex in the North Atlantic region, Mar. Biol., 98, 51-60, doi:10.1007/bf00392658, 1988.

Versteegh, E. A. A., Troelstra, S. R., Vonhof, H. B., and Kroon, D.: Oxygen isotopic composition of bivalve seasonal growth increments and ambient water in the rivers Rhine and Meuse, Palaios, 24, 497-504, doi:10.2110/palo.2008.p08-071r, 2009.

Versteegh, E. A. A., Vonhof, H. B., Troelstra, S. R., Kaandorp, R. J. G., and Kroon, D.: Seasonally resolved growth of freshwater bivalves determined by oxygen and carbon isotope shell chemistry, Geochem. Geophy. Geosy., 11, Q08022, doi:10.1029/2009GC002961, 2010a.

Versteegh, E. A. A., Vonhof, H. B., Troelstra, S. R., and Kroon, D.: A molluscan perspective on hydrological cycle dynamics in northwestern Europe, Netherlands Journal of Geosciences, 89, 49-58, 2010b.

Versteegh, E. A. A., Vonhof, H. B., Troelstra, S. R., and Kroon, D.: Can shells of freshwater mussels (Unionidae) be used to estimate low summer discharge of rivers and associated droughts?, IJEaS, 100, 1423-1432, doi:10.1007/s00531-010-0551-0, 2011.

Wanamaker Jr., A. D., Kreutz, K. J., Borns Jr., H. W., Introne, D. S., Feindel, S., and Barber, B. J.: An aquaculture-based method for calibrated bivalve isotope paleothermometry, Geochem. Geophy. Geosy., 7, Q09011, doi:10.1029/2005GC001189, 2006.

Wanamaker Jr., A. D., Kreutz, K. J., Borns Jr., H. W., Introne, D. S., Feindel, S., Funder, S., Rawson, P. D., and Barber, B. J.: Experimental determination of salinity, temperature, growth, and metabolic effects on shell isotope chemistry of Mytilus edulis collected from Maine and Greenland, Paleoceanography, 22, PA2217, doi:10.1029/2006PA001352, 2007.

Wanamaker Jr., A. D., Kreutz, K. J., Schöne, B. R., and Introne, D. S.: Gulf of Maine shells reveal changes in seawater temperature 
seasonality during the Medieval Climate Anomaly and the Little Ice Age, Palaeogeogr. Palaeoclimatol. Palaeoecol., 302, 43-51, doi:10.1016/j.palaeo.2010.06.005, 2011.

Watanabe, T., Suzuki, A., Minobe, S., Kawashima, T., Kameo, K., Minoshima, K., Aguilar, Y. M., Wani, R., Kawahata, H., Sowa, K., Nagai, T., and Kase, T.: Permanent El Niño during the Pliocene warm period not supported by coral evidence, Nature, 471, 209-211, doi:10.1038/nature09777, 2011.

Westerbom, M. W., Kilpi, M. K., and Mustonen, O. M.: Blue mussels, Mytilus edulis, at the edge of the range: population structure, growth and biomass along a salinity gradient in the north-eastern Baltic Sea, Mar. Biol., 140, 991-999, doi:10.1007/s00227-0010765-6, 2002.
Williams, B., Halfar, J., Steneck, R. S., Wortmann, U. G., Hetzinger, S., Adey, W., Lebednik, P., and Joachimski, M.: Twentieth century $\delta^{13} \mathrm{C}$ variability in surface water dissolved inorganic carbon recorded by coralline algae in the northern North Pacific Ocean and the Bering Sea, BGeo, 8, 165-174, doi:10.5194/bg-8-1652011, 2011.

Yanes, Y., Romanek, C. S., Molina, F., Cámara, J. A., and Delgado, A.: Holocene paleoenvironment $(\sim 7200-4000$ cal BP) of the Los Castillejos archaeological site (SE Spain) inferred from the stable isotopes of land snail shells, Quaternary Int., 244, 67-75, doi:10.1016/j.quaint.2011.04.031, 2011. 